\title{
Reversal of Cellular Roles in Angiogenesis: Implications for Anti-Angiogenic Therapy
}

\author{
Daniela Virgintino ${ }^{c}$ Ugur Ozerdem $^{a}$ Francesco Girolamo ${ }^{c}$ Luisa Roncali ${ }^{c}$ \\ William B. Stallcup $^{b}$ Roberto Perris ${ }^{d}$ \\ a La Jolla Institute for Molecular Medicine, San Diego, and ${ }^{\mathrm{b}}$ Burnham Institute for Medical Biology, La Jolla, Calif., \\ USA; ' Department of Human Anatomy and Histology, University of Bari School of Medicine, Bari, and \\ ${ }^{\mathrm{d} D e p a r t m e n t}$ of Genetics, Microbiology and Anthropology, University of Parma, Parma, and Division for \\ Experimental Oncology 2, National Cancer Institute Aviano, Aviano, Italy
}

Whether occurring during embryonic development, in pathophysiological conditions, such as wound healing/ tissue regeneration, or in fully pathological conditions, such as cancer and inflammatory diseases, angiogenesis is traditionally thought to be a strongly endotheliumdriven process. In fact, the main features of the angiogenic model, largely preserved as first proposed by Folkman [1] in 1971, implicate endothelial cells as primary effectors of the tubulogenesis process [2]. As depicted in figure 1a, pro-angiogenic growth factors (especially VEGF) trigger endothelial cell activation, proliferation and motility. In addition to resident endothelial cells, circulating endothelial precursors may also participate in the formation of interconnected neotubules [3]. Another crucial role is played by local pericytes or bone marrowderived pericyte progenitors [4-6]. According to the angiogenesis dogma, pericytes are recruited by migrating endothelial cells to confer stability to nascent vascular structures [2, 4-7]. Indeed, targeting pericytes through NG2 proteoglycan [8] or PDGFR $\beta[5,6]$ strongly impacts neovasculogenesis and may also affect lymphangiogenesis.

D.V. and U.O. contributed equally to this paper.

\section{KARGER}

Fax +41613061234 E-Mail karger@karger.ch www.karger.com (c) 2007 S. Karger AG, Basel

$1018-1172 / 08 / 0452-0129 \$ 24.50 / 0$

Accessible online at:

www.karger.com/jvr
Our recent observations suggest that the reduced levels of vascularization observed in pericyte targeting paradigms are due to a reversal of the roles proposed for endothelial and pericytic cells in the traditional model (fig. 1a). During normal angiogenesis in fetal human brain (fig. 1b-d) [8], in murine tumor models (fig. 1e-g) [9], in subcutaneous Matrigel plug assays and in adult mouse cornea [7], cord-like structures composed solely of pericytes are observed at the sprouting front (see also online suppl. fig. S1; www.karger.com/doi/10.1159/ 000109965). These cords appear to serve as guiding structures for the progressive invasion of endothelial cells to construct the mature vessel (see also suppl. video 1; www.karger.com/doi/10.1159/000109965).

A high-resolution microscopic imaging of fetal angiogenesis in human brain (fig. $1 \mathrm{~h}$, i) reveals that following disruption of the subendothelial basement membrane during sprouting, a new one appears to be laid down by early emigrating pericytes at the distal end of the sprouts and invest these cells $[10,11]$. Closer examination of the angiogenic sprouts of fetal human brain further identifies mitotic endothelial cells at the proximal base of the sprout (fig. 1h, i) rather than at its distal end. This observation contrasts with the migration-proliferation relationship proposed for endothelial cells in the classical angiogenesis model: rather than undergoing division sub-

Prof. Roberto Perris

Department of Genetics, Microbiology and Anthropology

University of Parma, Via G.P. Usberti 11/A

IT-43100 Parma (Italy)

Tel. +39 0521906 601, Fax +390521906 019, E-Mail rperris@cro.it 


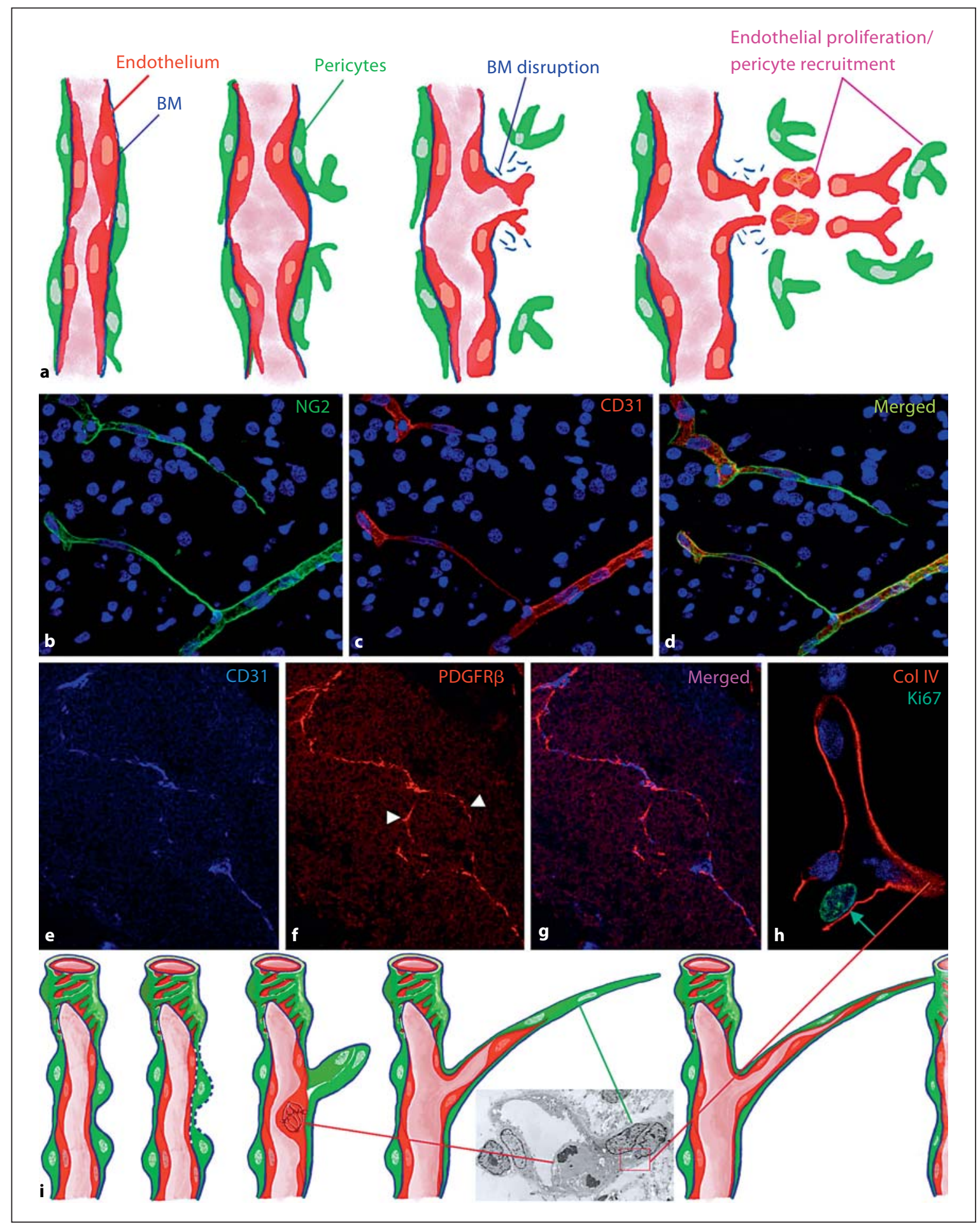

Fig. 1. a Classical view of the process of angiogenesis (modified from Bergers [2]). Pericyte and endothelial cell activation and coincident basement membrane (BM) disruption initiate the sprouting process. Endothelial cells become motile and proliferate in sufficient numbers to form new tubular structures, which are then invested by pericytes. b-d Dynamics of the angiogenic process in the developing human brain where cords of pericytes ex- tend from a preexisting capillary to connect with another vessel (see also suppl. video at www.karger.com/doi/10.1159/000109965). Subsequently, endothelial cells use the pericyte cords for guidance, and infiltrate the cords to organize nascent vascular tubules. e-g Low-magnification view of angiogenic sprouts around and within a uveal melanoma growing in an immunosuppressed mouse (orthotopic OCM-1A model). PDGFR $\beta$-positive pericytes 
sequent to their sprouting migration, endothelial cells proliferate prior to beginning their movement along pericyte cords. In summary, pericytes initiate sprouting by forming strands connecting to existing capillaries, and endothelial cells utilize these 'cellular cables' as guidance cues during their post-mitotic movement to complete vessel assembly. While preserving the crucial role of the intimate interplay between the two vascular cell types, repeatedly demonstrated to be crucial during vessel formation and maturation, the new paradigm assigns an un- precedented morphogenetic role to pericytes in the angiogenic process. The reversal of endothelial and pericytic cell roles during the initial phases of this phenomenon suggests that we reconsider the rationale of current anti-angiogenic therapies. Despite the promising clinical utility of interfering with VEGF signalling, combined [12] or selective pericy te targeting may prove more efficacious in abrogating unwanted neoscularization without causing vascular side effects.

\section{References}

1 Folkman J: Tumor angiogenesis: therapeutic implications. N Engl J Med 1971;285:11821186.

2 Bergers G, Benjamin LE: Tumorigenesis and the angiogenic switch. Nat Rev Cancer 2003; 3:401-410.

3 Khurana R, Simons M: Endothelial progenitor cells: precursors for angiogenesis. Semin Thorac Cardiovasc Surg 2003;15:250-258.

4 Rajantie I, Ilmonen M, Alminaite A, Ozerdem U, Alitalo K, Salven P: Adult bone marrow-derived cells recruited during angiogenesis comprise precursors for periendothelial vascular mural cells. Blood 2004;104: 2084-2086.

5 Song S, Ewald AJ, Stallcup WB, Werb Z, Bergers G: PDGFR $\beta^{+}$perivascular progenitor cells in tumours regulate pericyte differentiation and vascular survival. Nat Cell Biol 2005;7:870-879.
6 Ozerdem U, Alitalo K, Salven P, Li A: Contribution of bone marrow-derived pericyte precursor cells to corneal vasculogenesis. Invest Ophthalmol Vis Sci 2005;46:35023506.

7 Nystrom HC, Lindblom P, Wickman A, Andersson I, Norlin J, Faldt J, Lindahl P, Skott O, Bjarnegard M, Fitzgerald SM, Caidahl K, Gan LM, Betsholtz C, Bergstrom G: Plateletderived growth factor $B$ retention is essential for development of normal structure and function of conduit vessels and capillaries. Cardiovasc Res 2006;71:557-565.

8 Von Tell D, Armulik A, Betsholtz C: Pericytes and vascular stability. Exp Cell Res 2006;312:623-629.
9 Ozerdem U, Stallcup WB: Pathological angiogenesis is reduced by targeting pericytes via the NG2 proteoglycan. Angiogenesis 2004;7:269-276.

10 Virgintino D, Girolamo F, Errede M, Capobianco C, Robertson D, Stallcup WB, Perris $\mathrm{R}$, Roncali L: An intimate interplay between precocious, migrating pericytes and endothelial cells governs human fetal brain angiogenesis. Angiogenesis 2007;10:35-45.

11 Ozerdem U, Stallcup WB: Early contribution of pericytes to angiogenic sprouting and tube formation. Angiogenesis 2003;6:241249 .

12 Pietras K, Hanahan D: A multitargeted, metronomic, and maximum-tolerated dose 'chemo-switch' regimen is antiangiogenic, producing objective responses and survival benefit in a mouse model of cancer. J Clin Oncol 2005;23:939-952. (arrowheads) form the sprouting front of an angiogenic capillary in advance of CD31-positive endothelium. $\mathbf{h}$ Endothelial cell division in angiogenic sprouts (human fetal brain) is primarily detected in cells at the base of the sprout, which is entirely surrounded by type IV collagen. i Revised angiogenesis model implicating activation of pericyte movement together with disruption of the surrounding basement membrane to initiate sprouting. Endothe- lial cells are then activated, proliferate locally and subsequently infiltrate the pericyte cords that have established connections with existing capillaries to shape the neovessel. Inset shows the ultrastructure of the base of an angiogenic sprout in the developing human brain, highlighting two protruding pericytes surrounded by a basement membrane-like matrix structure (boxed area) and a mitotic endothelial cell. 